\title{
The Differences Of Knowledge Management Principles About Early Detection Fibroadenoma Mammae (Fam) Using Sadari Method In Smpn 18 Banjarmasin
}

Siti Hateriah ${ }^{1 *}$

${ }^{1}$ Academy of Midwifery Sari Mulia Banjarmasin Indonesia

*siti_hateriah@akbidsarimulia.ac.id

Ika Mardiatul Ulfa ${ }^{1}$

${ }^{1}$ Academy of Midwifery Sari Mulia Banjarmasin Indonesia

Ika_mardiatul_ulfa@akbidsarimulia.ac.id

Betty Andirasari ${ }^{1}$

${ }^{1}$ Academy of Midwifery Sari Mulia Banjarmasin Indonesia bettyandirasari@gmail.com

\section{ABSTRACT}

Objective: The purpose of this research is to know the difference of knowledge of young woman before and after doing counseling about early detection of FAM using SADARI method in SMPN 18 Banjarmasin.

Methods: The research method used is Pre-Experiment Design method. In this research, the object is the girls of class VIII SMP 18 Banjarmasin. The sampling method used is Saturated Sampling which takes all members of the population into a sample of 77 respondents.

Results: The result of this research is $\alpha<p$ with $p=0000$ and $\alpha=0.05 \mathrm{Ha}$ in the accept and Ho rejected signal means that there is a difference of knowledge of young women about early detection of FAM using SADARI method in SMPN 18 Banjarmasin.

Conclusion: There are differences before and after the counseling about early detection of FAM using SADARI method in SMPN18 Banjarmasin. Suggested in young women is should be increased knowledge, especially in the field of health by reading health books and consult with health personnel and seek information.

Keywords: Counseling, early detection of FAM, knowledge, SADARI method, young women.

\section{INTRODUCTION}

In Indonesia the data of FAM disease is still unknown, but it is estimated every year to increase. Fibroadenoma mammae is a benign tumor in the breast that is bounded clearly and lump-shaped and can be moved.
Fibroadenoma mammae usually occurs in young women, ie at adolescence or age 20 years. In Indonesia, although it is unclear, the fibroadenoma generally occurs in women aged 21-25 years, less than $5 \%$ occur 
in the age above 50 years, while the prevalence is more than $9 \%$ of the female population affected by fibroadenoma.

While reports from Western Breast Services Alliance, fibroadenoma occurs in women with age between 15-25 years, and more than one in six (15\%) women have fibroadenoma in his life. However, the occurrence of fibroadenoma can occur in women with older age or even after menopause, certainly with a smaller number of incidents than at a young age. In Yaman began January 2006-December 2009 found as many as 635 cases were diagnosed as a disease of breast tumors. There are as many as 493 abnormalities (77.6\%) which is a disease of the breast tumors are benign and $142(22.4 \%)$, malignant diseases of breast tumors in the age range $40-49$ years. Of the 493 disease, benign breast tumors are most often happens is fibroadenoma $40.5 \%$ by age range 20-29 years [1].

Southeast Asian breast cancer occupy rank first $(86,842$ case) and the highest mortality $(36,723$ cases $)$ in women compared to other cancer cases [2]. Breast cancer in Indonesia was ranked the second most after cervical cancer [3]. In Indonesia there are an estimated 100 people new sufferers of breast cancer per 100,000 inhabitants. This means the number of 237 million inhabitants there are approximately 237,000 new cancer sufferers. In line with that, the empirical data also showed that cancer deaths over the years continued to increase and based on the results of the Riskesdas of the year 2007, approximately $5.7 \%$ of deaths of all ages caused malignant cancer [5].

The death rate due to breast cancer will remain high unless medical handling and enhanced screening program. The mortality rate in developing countries is much greater compared to developed countries. This can be attributed to a lack of public awareness of breast cancer, the absence of an organized screening program, presentation of breast cancer that appears in slowly, and lack of effective treatment options and easy access. It also results in late in the early detection of breast cancer. As a result of late early detection, most patients diagnosed with upright after breast cancer in an advanced stage and has been metastasis to other organs [6].

Tumor cells are the cells that undergo transformations that grows in autonomic control of cell growth. The breast is one of the important organs for womenfolk. In addition to completeness for a woman, breasts are also on view as a symbol of beauty. The breasts often refer to as the 
Crown of the women. In fact, there are opinions that State that breast gives big influence on beauty and the beauty of a woman. However, the breast still plays a role in the process of reproduction. However, the important role of the breast is not separated from the possibility of a problem that is attacking the breasts. Already when his woman is more sensitive and starts paying attention to breast organs in particular. The more we know the early problems that occur on the breast is getting early detection FAM can do [7].

Very early detection needs to be done to lower the mortality rate of breast cancer. For that, so the FAM can be detected early, the only way to detect early detection of FAM, a cheap but practical and accurate is breast self-examination (SADARI). Breast self-examination we recommend that you do the first day after menstruation when the breast is slack, so if there is a bump-bump be on the touch with ease. If the woman is no longer got the menstruation should specify certain one day for inspection, for example, every first day of each month [8].

Research conducted by Susanti in SMAN 2 Sukoharjo Surakarta (2011) results of test chi-square note that there is a relationship between knowledge of the attitudes towards breast cancer [9].
Preliminary results of a study performed in SMPN 18 Banjarmasin, out of 10 respondents I ask directly about early detection of FAM using SADARI method that in 10 respondents find it not knowing what it was and the FAM using SADARI method itself. Based on the above issue, the importance of for a woman capable of detecting early FAM with the method of SADARI. Therefore must be doing the research on young women about early detection FAM using SADARI method in SMPN 18 Banjarmasin.

The research is in line with the decision of the Minister of health no. 796 of the year 2010 about Clinical guidelines for breast cancer and cervical cancer who say that breast self-examination (SADARI) the routine as a guideline to increase awareness of the breast cancer [10].

Young women have a level of knowledge and understanding that is low on breast cancer and the way its detection. Although they know breast cancer is a serious disease, they just assume that the factors of age and genetic makeup can cause breast cancer so they hold that are not at risk of developing cancer of the breast [ 11.12]. There are a number of risk factors that have been known to cause breast cancer, namely 
age, genetic factors, and reproductive factors [13].

This research aims to know the difference of knowledge of young women before and after in doing outreach about early detection of FAM using SADARI method in SMPN 18 Banjarmasin.

\section{RESEARCH METHODS}

This research Method is the method of experimental Design Pre research i.e. research by giving pre-test prior to intervention in the form of extension, then do counseling with techniques lecture, after it's done post-test, so it can be seen the difference knowledge before and after illumination. The data collected from the score value in knowledge can be when done a pre-test before extension and knowledge when given a post-test after counseling.

Variable dependenthis research is knowledge of young women in SMPN 18 Banjarmasin and variable independen namely extension of early detection FAM using SADARI method, this research population. is teen SMPN 18 Banjarmasin class VIII that amounted to 77 people from December-February 2014 year 2015. On the study of samples taken with the technique of "sampling of saturated" large population in this research is as many as 77 people teen daughter in 22818 Banjarmasin from December 2014-2015 year Feb.

Data was collected by giving a pretest before, then the results are collected. After it's done post-test with the same problem then the result comparison between pre-test and posttest.

\section{RESULTS}

The number of students in SMPN 18 Banjarmasin as many as 479 students are divided into three classes, namely Class VII totaled 191 students, class VIII totaled 167 students, and class IX students numbered 121, where female students amounted to 211 people and male students amounted to 268 people. In this research that became a research sample was grade VIII SMP 18 Banjarmasin total 77 female students.

The following the results of the data analysis to find out the knowledge of young women 18 Years SMP Banjarmasin 2015 before and after the extension of early detection of FAM using SADARI method. 


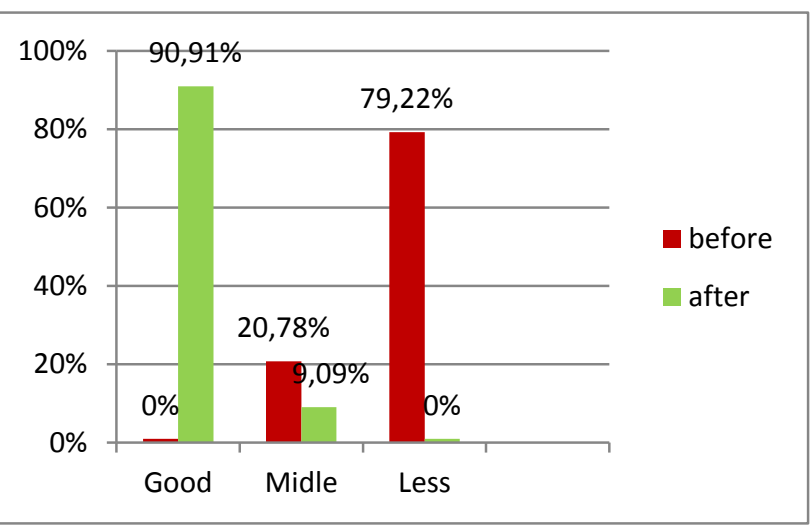

Figure 1. Diagram stem knowledge differences young women before and after in doing outreach about early detection FAM using SADARI method.

Based on the above results that get counseling before most respondents with less knowledge level i.e. as many as 61 people $(79.22 \%)$. While after done extension programs most respondents with a good level of knowledge that is as much as 70 people $(90.91 \%)$. With the results of a test of Wilcoxon Match Pairs Test value $\alpha<\mathrm{p}$ with $\mathrm{p}=0.000$ and $\alpha=0.05 \alpha<\mathrm{p}$ then you can deduce that there is a difference before and after the extension to knowledge about young women early detection of FAM using SADARI method.

\section{DISCUSSION}

Based on the results of research on the image of the diagram before the extension in the respondent's knowledge level get early detection FAM using SADARI method at the time before the extension is largely lacking. Less knowledge this can be caused because the respondent was the first high school students, in which respondents are still too early either in education or from the age that is still too young for cause is still the lack of knowledge and awareness of respondents on health in particular about the early detection of FAM. In addition, the respondents have not ever material or get counseling about health especially about early detection of FAM before, it is also possible to be one of the causes that contribute to the lack of knowledge of respondents about early detection of FAM. Other factors that also affect the level of knowledge is still the lack of information available both within the scope of the school as well as knowledge from outside the school.

Research results after extension most respondents with a good level of knowledge, so there is a difference between knowledge before extension compared with after the extension. The knowledge of the respondents mostly good and fairly after the do outreach in the form of granting the existence of knowledge because of guidance about early detection of FAM method and REALIZE by researchers with methods of lecture and question and answer. Methods lectures and $\mathrm{q}$ $\&$ an in deem very influentially in the success of outreach because with these methods more easily understand the respondent's 
information is given. In accordance with the theory of Notoatmodjo that health education is a method of speaking engagements, is a way of describing and explaining an idea, notion or orally to a group of targets so as to obtain information about health [14].

The results of this research also reinforced with research conducted by Permatasari, et al that the extension of SADARI as the early detection of breast cancer can effectively enhance the knowledge of students about SADARI [15].

One of the ways to increase knowledge about young women that is by SADARI educational. Research conducted by Gursoy, et. al., suggests that health education about SADARI can increase knowledge of young women about breast cancer and SADARI [16].

The research is in line with research conducted by Eka that knowledge and attitude young women in high school 1 Islam Yogyakarta 2012 after doing counseling about SADARI, the good category with results obtained. This means that the knowledge and attitudes are strongly influenced by media educational [17].

Expected to young women in SMPN 18 Banjarmasin to implement SADARI with routine in daily life to prevent breast cancer. And also expected the school SMPN 18
Banjarmasin to paste posters about the disease of breast cancer and SADARI in schools so that young women making can read it.

\section{CONCLUSION}

There is a difference before and after the extension to knowledge young women about early detection of FAM using SADARI method in SMPN 18 Banjarmasin. This research shows that the education of SADARI as the early detection of breast cancer can effectively enhance the knowledge of students about SADARI.

\section{REFERENCES}

[1]. Bafaker, S.S \& Bafana N. S Breast Disease in Southern Yemen. 2010. Hadramaunt

University.http://www.ncbi.nlm.nih.gov /pub med. di akses pada tanggal 19 desember 2013.

[2]. Kimman M., Norman R., Jan S., Kingstin D., Woodward M. The burdem of cancer in member countries of the association of southeast asian nations (ASEAN). Asian Pacific J Cancer Prev. 2012;13:411-420.

[3]. BKKBN. Pedoman Penanggulangan masalah kesehatan reproduksi melalui program KB Nasional. Jakarta 2009. 
[4]. Dalimartha, Setiawan. Kanker payudara, Dalam : Deteksi dini kanker dan simlisia antikanker. Swadaya, Surabaya. 2004.

[5]. Depkes. Latar belakang kanker payudara. 2012.

[6]. Sambanje MN, Mafuvadze B. Breast cancer knowledge and awareness among university students in Angola Pan African Medical Journal. 2012;11:70

[7]. Nisman, Wenny Artanty. Lima Menit Kenali Payudara Anda.Yogjakarta: CVAndi. 2011

[8]. Romauli, suryati \& Anna Vida Vindari. Kesehatan Reproduksi buat Mahasiswi Kebidanan . Yogyakarta. Nuha Medika. 2009.

[9]. Susanti, Dwi, Skripsi Hubungan antara pengetahuan dan sikap remaja tentang kanker payudara dengan prilaku periksa payudara sendiri (sadari) di SMA Negeri 2 Sukohartjo. 2011.

[10].Kemenkes RI. Keputusan menteri kesehatan Republik Indonesia Nomor 796 tentang pedoman teknis pengendalian kanker payudara dan kanker leher rahim. 2010.

[11]. Johnson, N., dan Dickson-Swift, V. 'It Ussually Happens in Older Women': Young Women's Perceptions About Breast Cancer, Health Educatioan Journal. 2008; 67 (4):243-275
[12].Tiolena, R. Faktor-faktor yang mempengaruhi keterlambatan pengobatan pada wanita penderita kanker payudara RSUP H. Adam Malik Medan tahun 2008. [Skripsi] Medan: Universitas Sumatera Utara, Fakultas Kesehatan Masyarakat. 2008.

[13]. Fuemmeler, BF., Penzich, MK., dan Tercyak, KP. Weight, Dietary Behavior, and Physical Activity in Childhood and Adolescence: Implication for Adult Cancer Risk. The European Journal of Obesity. 2009;(3):179-186

[14].Notoatmodjo, Soekidjo. metodologi penelitian kesehatan, edisi revisi. Jakarta: Rineka Cipta.2005.

[15].Permatasari,D., Fitriangga A., dan Handoko W. Efektifitas penyuluhan SADARI terhadap tingkat pengetahuan siswi SMA Negeri 2 di Kecamatan Pontianak Barat. Universitas Tanjungpura. Pontianak. 2013.

[16]. Gursoy, AA., Yigitbas, C., Yilmas F., Erdol H., Bulut HK., Mumcu Havva K., at. al. The effect of Peer Educatioan On Univesity Students' Knowledge Of Breast Self-Examination And Health Beiefs. The Journal of Breast Health. 2009;5(3):135-140. 
[17]. Eka, Annisa. Hikmah. Pengaruh penyuluhyan tentang pemeriksaan payudara sendiri (SADARI) terhadap sikap remaja putri di SMA Islam 1

Gamping. Yogyakarta 2012. 